\title{
Seasonal and inter-annual variation of bacteria in a seagrass bed of the Mediterranean Sea: relationship with labile organic compounds and other environmental factors
}

\author{
Roberto Danovaro $^{1,2}$, Mauro Fabiano ${ }^{2}$ \\ 'Istituto di Scienze Ambientali Marine, Università di Genova, S. Margherita L., Corso Rainusso 14, CP 79, \\ I-16038 Genova, Italy \\ ${ }^{2}$ Cattedra di Biologia Marina, Università di Ancona Monte d'Ago, I-60131 Ancona, Italy
}

\begin{abstract}
Seasonal and inter-annual variations in density and biomass of benthic bacteria were examined in the surface sediments of a Mediterranean seagrass bed [Posidonia oceanica (L.) Delile] in the Gulf of Marconi (northwestern Mediterranean Sea) from January 1990 to January 1992. Bacterial parameters were compared to changes in elemental (organic $C$ and total $N$ ) and biochemical (lipids, proteins, carbohydrates) composition of sediment organic matter, as well as to photosynthetic pigments. Bacterial density and biomass were high and exhibited marked seasonal variations with highest values in late spring. Bacterial biomass was positively correlated with temperature and negatively correlated with chlorophyll a content. By contrast no correlations were found with the bulk of organic carbon or nitrogen. In the year-to-year comparison the seasonal patterns of bacterial density were similar. However, bacterial parameters showed significant inter-annual variations. Such changes may be related to different organic matter composition and availability or to competition with microphytobenthos for inorganic nutrient uptake. These data evidence that, whereas temperature might be the most important factors controlling bacterial seasonality, the quality of organic matter (sedimentary protein content coupled to $\mathrm{C} / \mathrm{N}$ values) may be an important factor for explaining the inter-annual variations
\end{abstract}

KEY WORDS: Benthic bacteria P Posidonia oceanica - Labile organic compounds

\section{INTRODUCTION}

In the last decade several studies have shown that the role of bacteria in benthic food chain is far more important than previously thought (Meyer-Reil 1983, Moriarty \& Pollard 1982). Many animals feeding on sediment organic matter are more nutritionally dependent on attached bacteria than on the organic detritus (Newell \& Field 1983), so bacteria may represent one of the most important food sources for meio- and macrofauna (Bouvy 1988, Levinton \& Bianchi 1981).

It is generally assumed that bacterial distribution is related to sediment properties. Factors which may control benthic bacterial dynamics include physical characteristics (such as temperature and sediment type; Dale 1974, Griffiths et al. 1978, De Flaun \& Mayer 1983, Albertelli et al. 1992), chemical characteristics (such as organic matter content, Meyer-Reil 1987; con- centration of labile compounds, Danovaro et al. 1992, 1993, Fabiano \& Danovaro 1994; concentration of toxic trace metals, Fabiano et al. 1994) and biological processes such as grazing (Montagna 1984). Despite this, the identification of the factors which control bacterial distribution and activity has been a controversal issue.

Few studies deal with the seasonal development of microbial communities (Meyer-Reil 1983, Cammen \& Walker 1986, Duyl \& Kop 1990) and very little is known about seasonal patterns of bacterial populations in the Mediterranean (Herndl et al. 1987, Delille et al. 1990) and there are no known temporal studies longer than 1 yr.

Information on microbial communities associated with Posidonia oceanica is scarce (Velimirov et al. 1981. Novak 1984, Velimirov \& Walenta-Simon 1992, 1993) and information on Mediterranean seagrass bed is practically non-existent (Danovaro et al. 1994a). 
Therefore, it is important to gather more information on inter-annual variations of bacterial population to quantify carbon flow and to create predictive models.

This paper reports the seasonal and inter-annual variation of benthic bacteria in subtidal sediments of the Ligurian Sea (northwestern Mediterranean). Data relative to the period January 1991 to January 1992 were compared to a previous sampling period (Danovaro et al. 1994a). Bacterial dynamics were compared to changes in organic matter composition (both elemental and biochemical) and other environmental parameters (temperature, photosynthetic pigments) in order to understand the factors regulating bacterial dynamics in seagrass sediments.

\section{MATERIALS AND METHODS}

Study site. Sediment samples were collected on a fortnightly basis from January 1990 to January 1992 by Scuba divers in Prelo Bay, at $4 \mathrm{~m}$ depth in a Posidonia oceanica bed, Gulf of Marconi, Ligurian Sea (northwestern Mediterranean Sea; Fig. 1). Temperature was measured in situ during SCUBA diving. The study area is sheltered and characterized by low current speed at the water-sediment interface $\left(0.4\right.$ to $2.9 \mathrm{~cm} \mathrm{~s}^{-1}$; Danovaro 1993). The depth of the RPD (Redox Potential Discontinuity) ranges between 4.0 and $12.0 \mathrm{~cm}$. Grain size (on average Phi $=0.384$ ) does not change seasonally and porosity of sediment ranges between 22.1 and $55.7 \%$ (Danovaro 1993). In the study area,

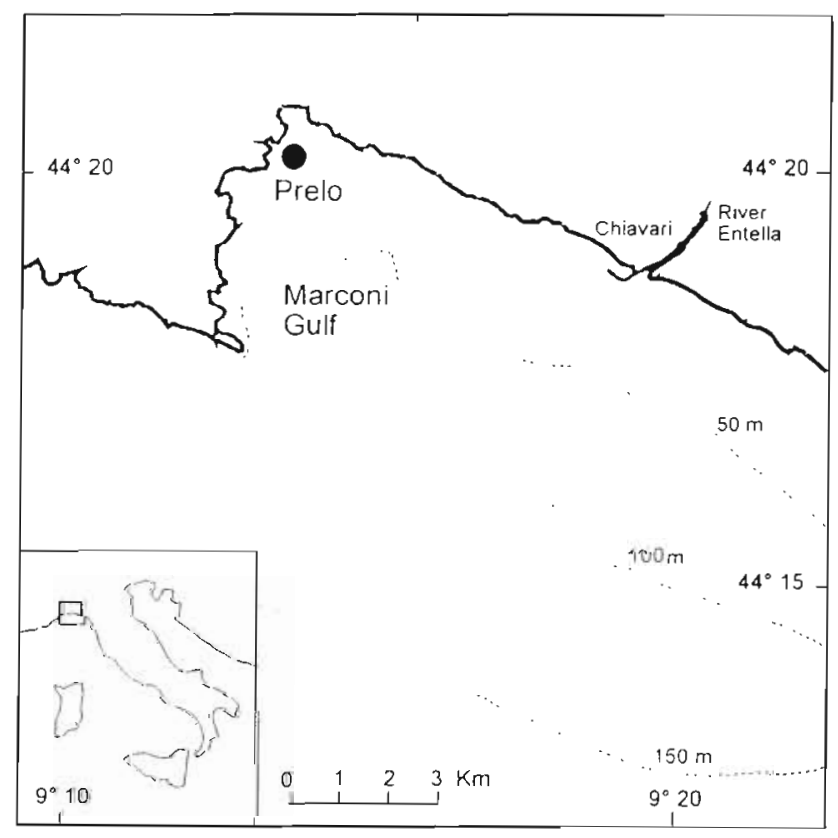

Fig. 1 The sampling station in the Marconi Gulf, Ligurian Sea (northwestern Mediterranean Sea)
Posidonia oceanica forms an almost continuous and dense belt ( 375 leaves $\mathrm{m}^{-2}$ ) from about 0.4 to $9.0 \mathrm{~m}$ depth. The dominant macrofauna in this station are the polychaete Spio decoratus (Bobretzky), the snail Bittium reticulatum (Da Costa), the bivalve Dosinia Iupinus (Linné), and the decapods Diogenes pugilator (Roux) and Hippomedon massiliensis (Bellan-Santini). Meiofauna is dominated by deposit-feeding nematodes (Danovaro 1993, Danovaro et al. 1994b).

Benthic bacteria. Three replicate cores were collected using sterile syringes $(0-0.5 \mathrm{~cm}$ sediment layer) and processed within $3 \mathrm{~h}$ of collection. Each replicate $\left(1 \mathrm{~cm}^{3}\right)$, was added to $10 \mathrm{ml} 0.2 \mu \mathrm{m}$ filtered sea water with prefiltered formalin $(2 \%)$. Samples were sonicated 3 times (Sonifier Tansonic Labor 2000,50 W for 1 min). Subsamples were diluted 100 to 500 times. Portions of the subsamples were stained for $3 \mathrm{~min}$ with acridine orange and filtered on black Nuclepore $0.2 \mu \mathrm{m}$ filters. The filters were analysed as described by Montagna (1982) using epifluorescence microscopy (Zeiss Universal Microscope). The number of dividing bacteria was determined. The contribution by different size classes of bacteria to the total biomass was followed by assigning bacteria into different size classes. Bacterial biovolume was converted to carbon content assuming $308 \mathrm{fg} \mathrm{C}$ per $\mu^{3}$ (Fry 1988). Average cell carbon content was calculated by dividing total bacterial biomass by total bacterial density. Data were normalized to dry weight after desiccation $\left(60^{\circ} \mathrm{C}, 24 \mathrm{~h}\right)$.

Sediment organic matter and photosynthetic pigments. Immediately after sampling, the surface layer $(0-1 \mathrm{~cm})$ of 3 replicate cores to be used for the sediment analyses was frozen at $-20^{\circ} \mathrm{C}$.

Total sediment organic carbon (OC) and nitrogen $(\mathrm{ON})$ were measured, after acidification with $0.1 \mathrm{~N}$ $\mathrm{HCl}$, in 4 replicates using a Carlo Erba CHN Analyzer (mod. EA 1108). Cyclohexanone-2,4-dinitrophenylhydrazone was used as standard (Hedges \& Stern 1983).

Lipids were extracted from dried sediment samples by direct elution with chloroform and methanol. Analyses were carried out using the methods of Bligh \& Dyer (1959) and of Marsh \& Weinstein (1966).

Protein analyses were carried out following an extraction with $\mathrm{NaOH}(0.5 \mathrm{M}, 4 \mathrm{~h})$ and were determined according to Hartree (1972) modified by Rice (1982) to compensate for phenol interference. Concentrations are referred to as albumin equivalents.

Carbohydrates were analysed according to Gerchacov \& Hatcher (1972) and expressed as glucose equivalents. This method is based on the same principle of the widely used method of Dubois et al. (1956) but is specifically adapted for carbohydrate determination in sediments.

For each analysis, blanks were made using sediments treated in muffle furnace $\left(550^{\circ} \mathrm{C}, 4 \mathrm{~h}\right)$. Biochem- 
ical analyses were carried out in 4 replicates. Method accuracy was tested against prepared standards and coefficient of variation (CV) were calculated: $0.5 \%$ and $0.9 \%$ for OC and ON respectively, $7.8 \%$ for lipids, $6.0 \%$ for carbohydrates and $6.6 \%$ for proteins

Chlorophyll (chl) $a$ and phaeopigment analyses were carried out according to Lorenzen \& Jeffrey (1980). Pigments were extracted with $90 \%$ acetone. The supernatant was used to determine the functional chl a and acidified with $0.1 \mathrm{~N} \mathrm{HCl}$ in order to estimate phaeopigments.

Statistical analyses. Differences over time within and between years in environmental factors and bacteria were tested using analysis of variance (ANOVA). Microbial and environmental parameters were 4 throot transformed when homogeneity of variance was rejected by an F-max test. Pearson's product-moment correlation analysis was used initially to examine relationships between bacteria and environmental factors. Because of the large number of correlation tests, the probability of a Type I error occurring is high. The significance level for all analyses was $95 \%$.

\section{RESULTS}

\section{Temperature}

The lowest temperature recorded at the water-sediment interface was $12.3^{\circ} \mathrm{C}$ (February 1991); temperatures above $20^{\circ} \mathrm{C}$ were generally observed between June and October. Highest temperature measured was $25.4^{\circ} \mathrm{C}$ (late August; Fig. 2)

\section{Benthic bacteria}

Bacterial densities (total bacterial number, TBN) fluctuated significantly over time and showed a clear seasonal cycle characterized in both years by 2 peaks in close sequence (Fig 3a): the first peak occurred in April 1990 and May 1991 (45.6 and $2.8 \times 10^{8}$ cells g $^{-1}$ sed. DW respectively) and the second in May-June 1990 and July 1991 (252.0 and $5.6 \times 10^{8}$ cells g $^{-1}$ sed DW respectively). Minimum density was recorded in February $1991\left(0.8 \times 10^{8}\right.$ cells $\mathrm{g}^{-1}$ sed. DW $)$. A similar trend was observed for bacterial biomass (BBM, ranging from 4.9 to $1182.8 \mu \mathrm{g} \mathrm{C} \mathrm{g}^{-1}$ sed. DW; Fig. 3b). Both TBN and BBM were higher in the first than in the second year ( $\mathrm{n}=30, \mathrm{p}<0.001$ ). Mean cell biomass varied from 3.03 to $10.55 \times 10^{-11} \mathrm{mg} \mathrm{C}$ cell $^{-1}$ (in July 1990 and early May 1990 respectively; Fig. 3c). Highest median cell biomass values preceded, in temporal scale, highest BBM values. Cell size was significantly higher in the second year of sampling ( $n=30, p<0.01)$. Seasonal variations of the frequency of dividing cells (FDC) are reported in Fig. 3d. FDC showed wide variations during the study period and ranged between 1.35 (April 1990) and $5.20 \%$ (February 1990). FDC was significantly higher in the first than in the second sampling year $(\mathrm{n}=30, \mathrm{p}<0.05)$. Bacterial carbon accounted, on average, for $6.23 \%$ of total organic carbon (Table 1 ).

\section{Organic matter composition and photosynthetic pigments}

Sedimentary organic carbon (OC) and nitrogen (ON) (Fig. 4a, b respectively) exhibited a clear seasonality, similar in the 2 years studied, characterized by a first peak in spring (15.80 and $2.15 \mathrm{mg} \mathrm{g}^{-1}$ of sediment DW for $O C$ and $O N$ respectively) and a second pronounced peak in late autumn-winter. $C / N$ ratios ranged between 6.8 (April 1991) and 26.7 (November 1990; Fig. 4c).

The concentrations of the 3 main biochemical components of the organic matter are reported in Fig. 5a, b, c (for carbohydrates, proteins and lipids respectively).
Fig. 2, Seasonal variations in temperature at the sediment/ water interface

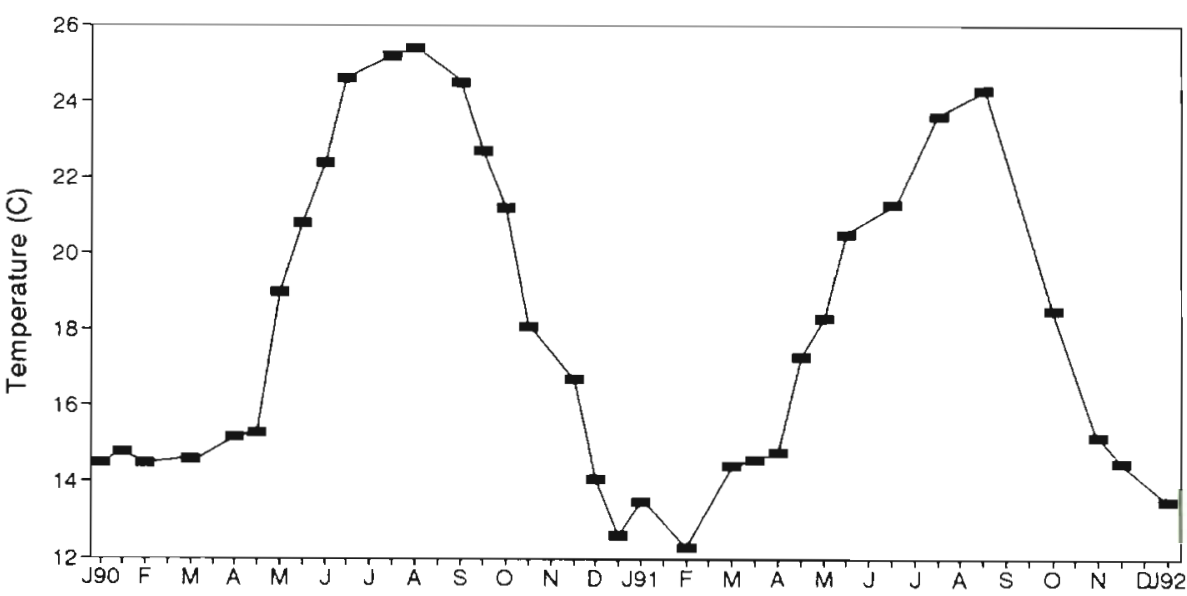





Fig. 3. Variations of bacteria parameters. (a) Total bacterial number (TBN), (b) bacterial biomass (BBM), (c) mean biomass per cell, (d) frequency of dividing cells (FDC) 


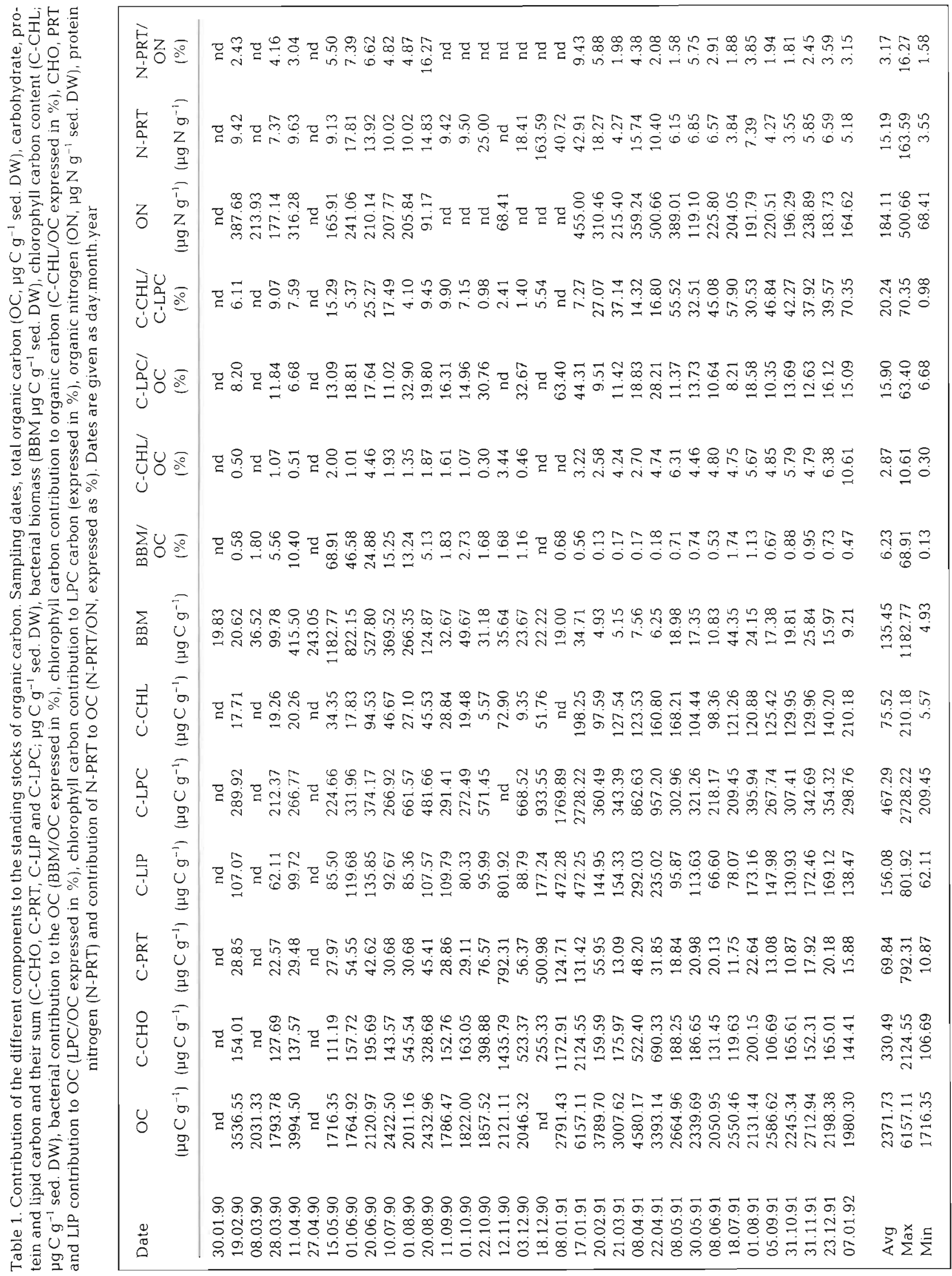



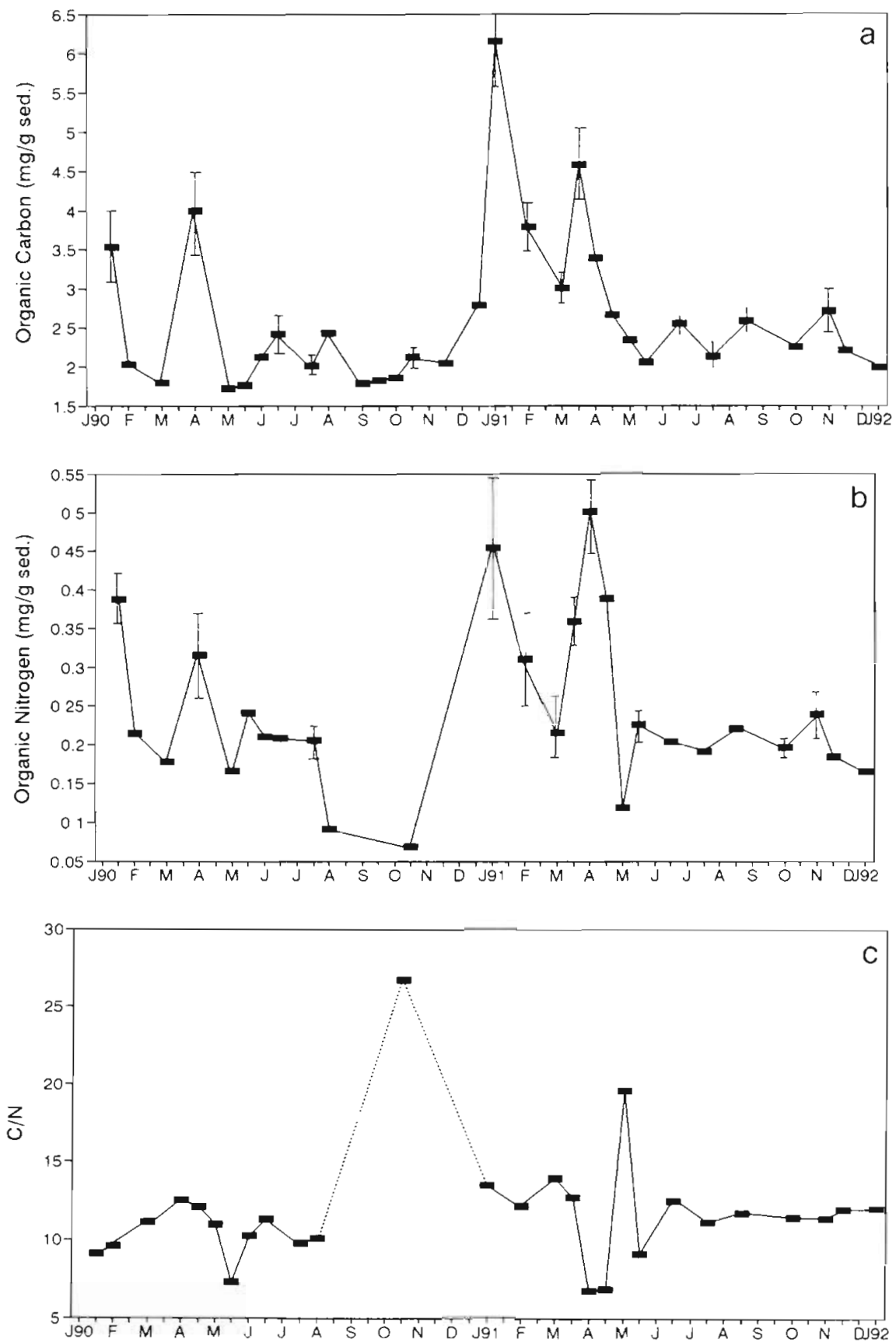

Fig. 4. Elemental composition of organic matter. (a) Total organic carbon (OC), (b) total organic nitrogen $(\mathrm{ON}),(\mathrm{c}) \mathrm{C} / \mathrm{N}$ ratio

They showed a common trend characterized by evident peaks in winter $\left(5311.4 \mathrm{\mu g} \mathrm{g}^{-1}, 1617.0 \mathrm{\mu g} \mathrm{g}^{-1}\right.$ and 1069.2 $\mu \mathrm{g} \mathrm{g}^{-1}$ of sediment DW for carbohydrates, proteins and lipids respectively) and low concentrations in summer. Carbohydrate concentrations fluctuated significantly over time but no significant differences were observed between the 2 years. Lipid content was higher in the second year than in the first $(n=30, p<0.05)$, by contrast protein concentrations were higher in the first year than in the second $(\mathrm{n}=30, \mathrm{p}<0.05)$.
Carbohydrate, protein and lipid concentrations were converted to carbon content assuming a $0.40,0.49$ and 0.75 factors according to the standard utilized and to literature references (Fichez 1991, Fabiano \& Danovaro 1994). The sum of carbohydrate, protein and lipid carbon (C-CHO, C-PRT and C-LIP) was utilized as relative measure of the amount of food potentially available for heterotrophic metabolism (C-LPC). C-LPC accounted on average for $15.90 \%$ of OC (Table 1). Nitrogen content of proteins (N-PRT) was calculated 
Fig. 5. Seasonal variations of the concentrations of main biochemical components of the organic matter: (a) carbohydrates, (b) proteins and (c) lipids
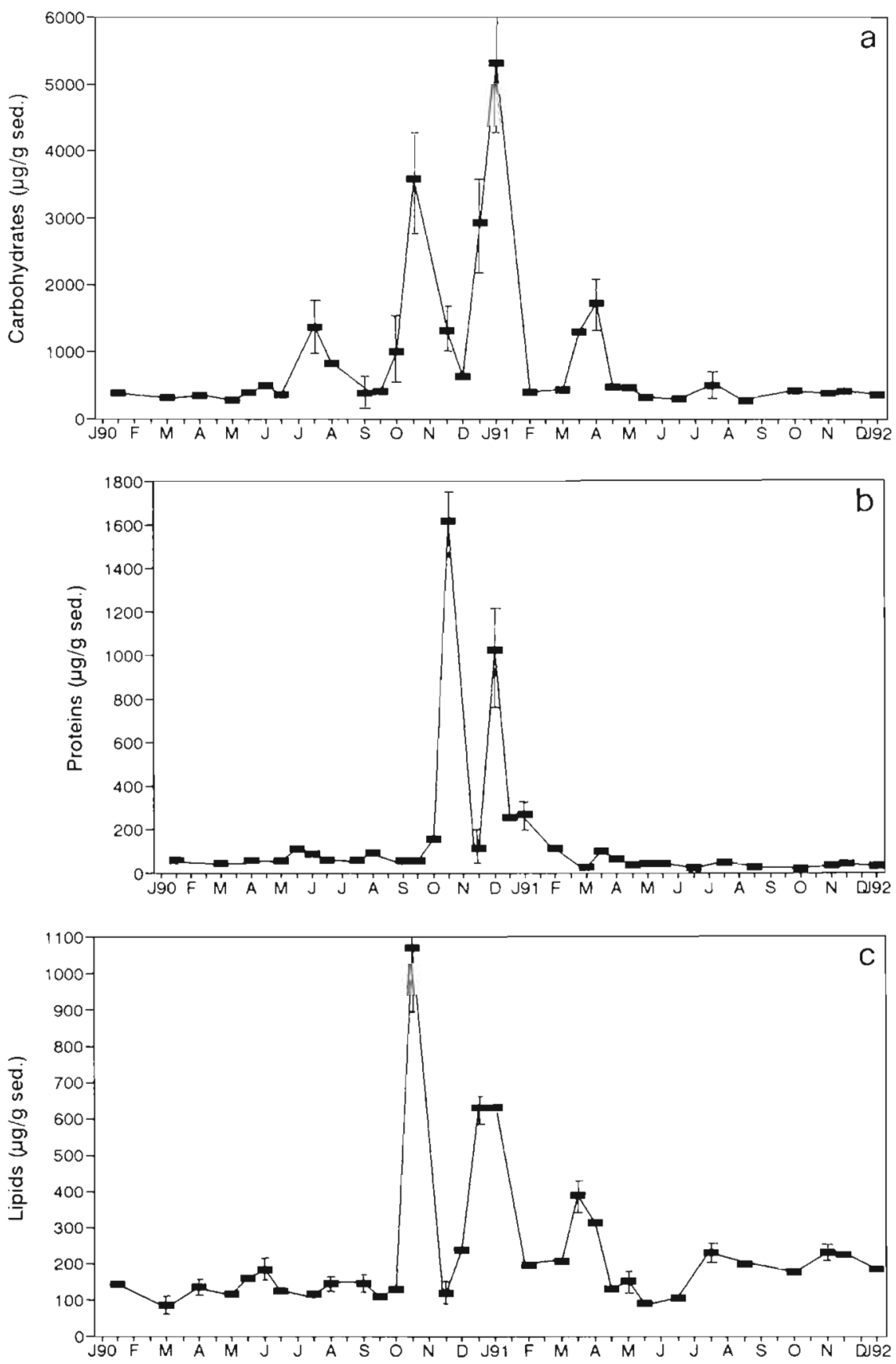

by dividing protein concentration by 6.25. N-PRT accounted on average for $3.17 \%$ of ON (Table 1).

Chl a concentrations in the uppermost $1 \mathrm{~cm}$ sediment layer (Fig. 6) showed strong seasonal variations characterized by 2 main peaks: the first in June 1990 and May 1991 (2.36 and 4.21 $\mu \mathrm{g}$ sed. DW respectively) and the second in winter (4.96 and $5.25 \mu \mathrm{g} \mathrm{g}^{-1}$ sed. DW respectively in January 1991 and 1992). Conversely, low chl a concentrations were found in summer. Significant differences in chl a content were observed comparing the 2 sampling years, the second being higher than the first ( $\mathrm{n}=30, \mathrm{p}<0.001$ ). Phaeopigment concentrations (Fig. 6) were low in spring and high in autumn-winter, ranging between 1.72 and $15.8 \mu \mathrm{g} \mathrm{g}^{-1}$ sed. DW respectively (May 1990 and November 1990). Chl a concentrations were converted to carbon content assuming a conversion factor 40 (De Jonge 1980). Chlorophyll carbon accounted, on average, for $2.87 \%$ of total organic carbon and for $20.24 \%$ of the C-LPC (Table 1). 


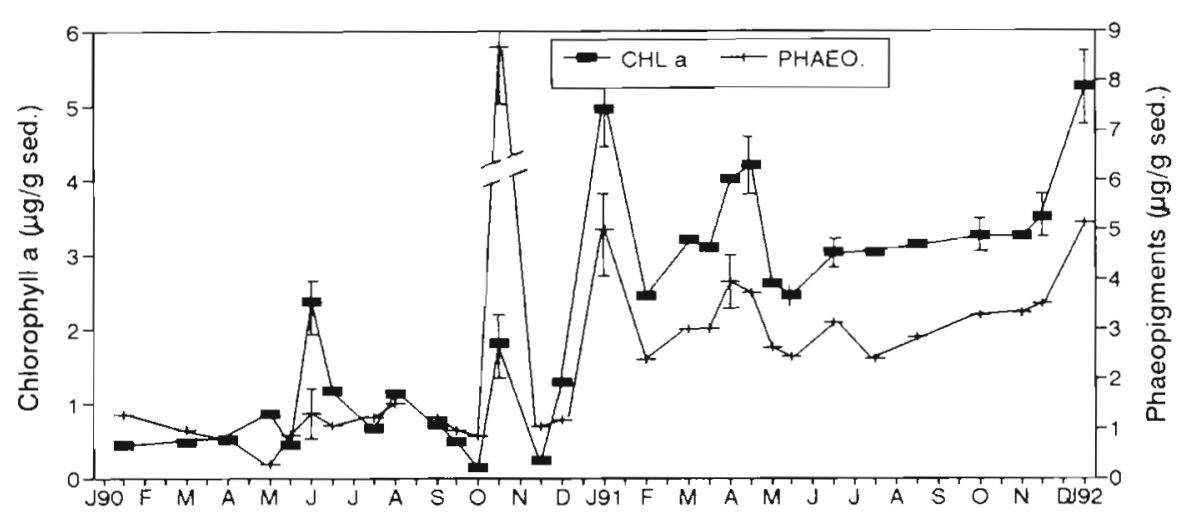

Fig. 6. Seasonal variations of chlorophyll $a$ and phaeopigment concentrations ( $\mu \mathrm{g} \mathrm{g}^{-1}$ sed. DW)

\section{DISCUSSION}

\section{Significance of bacteria in the seagrass system}

Bacterial densities in Prelo Bay were high when compared to other coastal areas (De Flaun \& Mayer 1983, Meyer-Reil 1983, Montagna et al. 1983, Herndl et al. 1989, Delille et al. 1990, Ferrara-Guerrero \& Bianchi 1990, Amon \& Herndl 1991, Albertelli et al. 1992) and bacterial biomass was a significant fraction (on average $6.23 \%$ ) of the sedimentary organic carbon. This value appears to be similar to those reported for deep-sea sediments (on average $9.5 \%$; Danovaro et al. 1993) but high if compared to other areas of the Ligurian Sea (3.5\%; Fabiano \& Danovaro 1994). Moreover, bacterial contribution to the bulk of organic carbon in the seagrass bed is higher than values reported in literature from other subtidal or intertidal areas: 0.2 to $0.7 \%$ (Meyer-Reil et al. 1980), 1.2\% (Dale 1974), $1.5 \%$ (Meyer-Reil 1984). Such differences indicate that the role of benthic bacteria in seagrass sediments is quantitatively similar to that played in deep-sea areas and by far more important than in other coastal systems. Conversely, chlorophyll carbon contributed little (less than $3 \%$ ) to the total organic carbon so that bacteria in seagrass beds may represent the main potential food source for sediment ingesting organisms.

\section{Seasonal dynamics of benthic bacteria}

Benthic bacteria in the Posidonia oceanica bed are characterized by evident and predictable seasonality. Generally benthic bacteria respond rapidly to ecological events such as the input of organic matter (MeyerReil 1983, 1986, 1987, Herndl et al. 1987). Although in both years strong organic carbon inputs were observed in spring and winter, they were different in composition and in terms of availability for bacterial communities. The high $O C$ and $O N$ values reported in cold months were characterized by high $\mathrm{C} / \mathrm{N}$ values, and
C-LPC generally accounted for a small fraction of the total carbon. Winter organic inputs have 2 most important sources: terrestrial run-off (due to heavy rain precipitations) and deposition of seagrass leaves (which are, in this period, at the end of the seasonal cycle) and in both cases organic matter is of highly refractory composition. This was confirmed by the analysis of the dynamics of photosynthetic pigments which indicated the presence of the algal bloom in spring and the deposition (as suggested by the high phaeopigment concentrations) of the seagrass leaves and epiphytes in winter. The limited food availability coupled with cold temperatures may be responsible for the low bacterial density and biomass characteristic of the winter period.

In this study bacterial number and biomass were significantly correlated to temperature at the water/sediment interface $\left(n=30, r=0.561 p<0.01\right.$ for $\mathrm{TBN}_{\text {; }} \mathrm{r}=$ $0.546, p<0.01$ for BBM). These results are consistent with those of De Flaun \& Mayer (1983), who observed a positive correlation between bacterial density and temperature. However, highest cell size, TBN and BBM values usually preceded temperature peaks. Therefore, despite the presence of a significant relationship, temperature cannot be considered the factor promoting bacterial development, but simply a factor which may sustain or increase bacterial growth. By contrast, high BBM values were observed in correspondence of high C-LPC values and high C-LPC/OC percentages, coupled with low $\mathrm{C} / \mathrm{N}$ ratios. Thus, apparently, the quality of the organic matter is the factor promoting (especially in spring and early summer) bacterial development. On a spatial scale, similar results were observed by Fabiano \& Danovaro (1994) who found a significant correlation between bacterial densities and the concentrations of proteins

The average cell carbon content $\left(6.05 \times 10^{-11} \mathrm{mg} \mathrm{C}\right.$ cell ${ }^{-1}$ ) is higher than values reported for bacteria in seagrass bed (on average $2.5 \times 10^{-11} \mathrm{mg} \mathrm{C}$ cell $^{-1}$; Moriarty \& Pollard 1982). It should be taken into account that different conversion factors for the calculation of the bacterial carbon content were used. Nevertheless, 
the presence of large bacterial cells would suggest that bacteria were not limited by food. Moreover, as indicated by the significant correlation between chl $a$ and cell biomass ( $\mathrm{n}=30, \mathrm{r}=0.423, \mathrm{p}<0.05$ ), larger cells were generally observed in correspondence with the spring and autumn blooms when high concentrations of labile organic compounds were observed. The frequency of dividing cells (FDC, on average $2.6 \%$ ) is in the range of literature data (Meyer-Reil 1983, Albertelli et al. 1992, Danovaro et al. 1993) but seasonal FDC patterns are not significantly related to any environmental parameter.

On the other hand, bacteria were negatively correlated to chl a content (which may be considered as measure of algal biomass) ( $n=30, r=0.562, p<0.01$ ). This relation may be due to Type I error in the correlation analysis. However, a possible explanation could be that both components were competing for inorganic nutrients (Kirchman et al. 1989). In fact, recently it has been demonstrated that heterotrophic bacterial growth can be stimulated by inorganic nutrients and that, in the presence of nitrogenous or phosphorous supplements, bacterial numbers increased approximately 3-fold (Horrigan et al. 1988). Positive correlations do not, a priori, guarantee cause and effect, and we can not clarify which factor, among several, is responsible for such kind of correlation. However, if bacteria use inorganic nutrients as alternative source they may limit autotrophic production by competing for nutrients (Parsons et al. 1981).

\section{Inter-annual variations of bacterial parameters}

The significant variation of bacterial parameters between the 2 sampling years cannot be explained with temperature. At the same time, whereas bacterial density, biomass and frequency of dividing cells were higher in the first year, organic carbon and chl a (which are usually utilized as measure of the organic matter available for heterotrophic metabolism) were significantly lower. Therefore, these factors cannot support bacterial development. The only exception is represented by protein content which was significantly higher in the first sampling year and which may represent the most suitable substrate for bacterial growth. This relation between bacterial density and protein content is not spurious since it has been demonstrated that bacteria contribute only for a small fraction to the total amount of proteins (about 2.5\%; Fabiano \& Danovaro 1993).

Acknowledgements. We are particularly grateful to Prof. N Della Croce (Genova, Italy) for providing laboratory facilities. R.D. was supported by a doctoral grant of the Ministero dell'Università e della Ricerca Scientifica, Italy.

\section{LITERATURE CITED}

Albertelli G, Fabiano M, Danovaro R, Fraschetti S (1992) Bacteria and macrofauna in different biocoenoses (Ligurian Sea). In: Atti IX Congr. Italian Association of Limnology and Oceanology AlOL, p 387-394

Amon RMW, Herndl GJ (1991) Deposit feeding and sediment: I. Interrelationship between Holothuria tubulosa (Holothuroidea, Echinodermata) and the sediment microbial community. PSZN I: Mar Ecol 12:163-174

Bligh EG, Dyer W (1959) A rapid method for total lipid extraction and purification. Can J Biochem Physiol 37:911-917

Bouvy M (1988) Contribution of the bacterial and microphytobenthic microflora in the energetic demand of the meiobenthos in an intertidal muddy sediment (Kerguelen Archipelago). PSZN I: Mar Ecol 9:109-122

Cammen LM, Walker JA (1986) The relationship between bacteria and micro-algae of a Bay of Fundy mudflat. Estuar coast Shelf Sci 22:91-99

Dale NC (1974) Bacteria in intertidal sediments: factors related to their distribution. Limnol Oceanogr 19:509-518

Danovaro R (1993) Analisi della dinamica e della struttura trofica di comunità meiobentoniche in relazione al contenuto ed alla composizione della sostanza organica particellata (Mar Ligure). PhD dissertation, University of Pisa

Danovaro R, Boyer M. Fabiano M (1992) Benthic bacterial abundance and distribution in different areas of the Mediterranean Sea: relationships with organic matter. Rapp Comm int Mer Médit 33:34

Danovaro R, Fabiano M. Della Croce N (1993) Labile organic matter and microbial biomasses in deep sea sediments (Eastern Mediterranean Sea). Deep Sea Res 40:953-965

Danovaro R, Fabiano M, Boyer M (1994a) Seasonal changes of benthic bacteria in a seagrass (Posidonia oceanica) bed in relation to the origin, composition and fate of the sediment organic matter. Mar Biol 119:489-500

Danovaro R, Mees J, Vincx M (1994b) Annual dynamics of meiobenthic communities in the Ligurian Sea (North Western Mediterranean): preliminary results. In: Atti $X$ Congr. Italian Association of Limnology and Oceanology (AIOL), p 295-305

De Flaun MF, Mayer LM (1983) Relationships between bacteria and grain surface in intertidal sediments. Limnol Oceanogr 28:873-881

De Jonge VE (1980) Fluctuations in the organic carbon to chlorophyll a ratios for estuarine benthic diatom populations. Mar Ecol Prog Ser 2:345-353

Delille D, Guidi LD, Cahet G (1990) Temporal variations of benthic bacterial microflora on the North Western Mediterranean continental shelf and slope. PSZN I: Mar Ecol 11:105-115

Dubois M, Gilles KA, Hamilton JK, Rebers PA, Smith F (1956) Colorimetric method for determination of sugars and related substances. Analyt Chem 28:350-356

Duyl FC van, Kop AJ (1990) Seasonal patterns of bacterial production and biomass in intertidal sediments of the western Dutch Wadden Sea. Mar Ecol Prog Ser 59 249-261

Fabiano M, Danovaro R (1994) Composition of organic matter in sediments facing a river estuary (Tyrrhenian Sea): relationships with bacteria and microphytobenthic biomass Hydrobiologia 277:71-84

Fabiano M, Danovaro R, Magi E, Mazzucotelli G (1994) Effects of heavy metal on benthic bacteria in coastal marine sediments: a field result. Mar Pollut Bull 28:18-23

Ferrara-Guerrero MJ, Bianchi A (1990) Distribution of microaerophilic bacteria through the oxic-anoxic transition zone 
of lagoon sediments. Hydrobiologia 207:147-152

Fichez R (1991) Composition and fate of organic matter in submarine cave: implications for the biogeochemical cycle of organic carbon. Oceanol Acta 14:369-377

Fry JC (1988) Determination of bromass. In: Austin B (ed) Methods in aquatic bacteriology. $J$ Wiley \& Sons Ltd, p 27-72

Gerchakov SM, Hatcher PG (1972) Improved technique for analysis of carbohydrates in sediments. Limnol Oceanogr 17:938-943

Griffiths RP, Hayasaka SS, McNamara TM, Morita RY (1978) Relative microbial activity and bacteria concentrations in water and sediment samples taken in the Beaufort Sea. Can J Microbiol 24:1217-1226

Hartree EF (1972) Determination of proteins: a modification of the Lowry method that gives a linear photometric response. Analyt Biochem 48:422-427

Hedges JI, Stern JH (1983) Carbon and nitrogen determination of carbonate-containing solids. Limnol Oceanogr 29: $657-668$

Herndl GJ, Faganelli J, Fanuko N, Peduzzi P. Turk V (1987) Role of bacteria in the carbon and nitrogen flow between water-column and sediment in a shallow marine bay (Bay of Piran, Northern Adriatic Sea). PSZN I: Mar Ecol 8: $221-236$

Herndl GJ, Peduzzi P, Fanuko N (1989) Benthic community metabolism and microbial dynamics in the Gulf of Trieste (Northern Adriatic Sea). Mar Ecol Prog Ser 53:169-178

Horrigan SG, Hagström A, Koike I, Azam F (1988) Inorganic nitrogen utilization by assemblages of marine bacteria in seawater culture. Mar Ecol Prog Ser 50:147-150

Kirchman D, Soto Y, Van Wambeke F, Bianchi M (1989) Bacterial production in the Rhône River plume: effect of mixing on relationships among microbial assemblages. Mar Ecol Prog Ser 53:267-275

Levinton J, Bianchi $T$ \{1981) Nutrition and food limitation of deposit-feeders. I. The role of microbes in the growth of mud snails (Hydrobiidae). J mar Res 39:531-545

Lorenzen C, Jeffrey J (1980) Determination of chlorophyll in sea water UNESCO Tech Pap mar Sci 35:1-20

Marsh JB, Weinstein WJ (1966) A simple charring method for determination of lipids. J Lip Res 7:574-576

Meyer-Reil LA (1983) Benthic response to sedimentation events during autumn to spring at a shallow water station in the Western Kiel Bight. II. Analysis of benthic bacternal populations. Mar Biol 77:247-256

Meyer-Reil LA (1984) Bacterial biomass and heterotrophic activity in sediments and overlying waters. In: Hobbie JE, Williams PJ LeB (eds) Heterotrophic activity in the sea. Plenum Press, New York, p 523-546

Meyer-Reil LA (1986) Spatial and temporal distrubution of bactenal populations in marine shallow water surface sediments. In: Lasserre P, Martin JM (eds) Brogeochemical processes at the land-sea boundary. Elsevier, Amsterdam, p $141-160$

Meyer-Reil LA (1987) Seasonal and spatial distribution of extracellular enzymatic activities and mucrobial incorporation of dissolved organic substrates in marine sediments. Appl environ Microbiol 53:1748-1755

Meyer-Reil LA, Bölter M, Dawson G, Liebezeit G, Szwerinski $H$, Wolter K (1980) Interrelationships between microbiological and chemical parameters of sandy beach sediments, a summer aspect. Appl environ Microbiol 39: $797-802$

Montagna PA (1982) Sampling design and enumeration statistics for bacteria from marine sediments. Appl environ Microbial 43:1366-1372

Montagna PA (1984) In situ measurement of meiobenthic grazing rates on sediment bacteria and edaphic diatoms. Mar Ecol Prog Ser 18:119-130

Montagna PA, Coull CB, Herring TL, Dudley BW (1983 The relationship between abundances of meiofauna and their suspected microbial food (diatoms and bacteria). Estuar coast Shelf Sci 17:381-394

Moriarty DJW, Pollard PC (1982) Diel variation of bacterial productivity in seagrass (Zostera capricorni) beds measured by rate of thymidine incorporation into DNA. Mar Biol 72:165-173

Newell RC, Field JG (1983) The contribution of bacteria and detritus to carbon and nitrogen flow in a benthic community. Mar Biol Lett 4:23-36

Novak R (1984) A study in ultra-ecology: microorganisms on the seagrass Posidonia oceanica (L.) Delile. PSZN I: Mar Ecol 5:143-190

Parsons TR, Albright LJ, Whitney F, Wong CS, Williams PJ LeB (1981) The effect of glucose on the productivity of seawater: an experimental approach using controlled aquatic ecosystems. Mar environ Res 4:229-242

Rice DL (1982) The detritus nitrogen problem: new observations and perspectives from organic geochemistry. Mar Ecol Prog Ser 9:153-162

Velimirov B, Ott JA, Novak R (1981) Microorganisms on macrophyte debris: biodegradation and its implication in the food web. Kiel Meeresforsch, Sonderh 5:333-344

Velimirov B, Walenta-Simon M (1992) Seasonal changes in specific growth rates, production and biomass of a bacterial community in the water column above a Mediterranean seagrass system. Mar Ecol Prog Ser 80:237-248

Velimirov B, Walenta-Simon M (1993) Bacterial growth rates and productivity within a seagrass system: seasonal variations in a Posidonia oceanica bed. Mar Ecol Prog Ser 96:101-107 